\title{
Chryseomicrobium imtechense gen. nov., sp. nov., a new member of the family Planococcaceae
}

\author{
Pankaj Kumar Arora, Archana Chauhan, Bhawana Pant, Suresh Korpole, \\ Shanmugam Mayilraj and Rakesh Kumar Jaint
}

Correspondence Pankaj Kumar Arora arora484@gmail.com
Environmental Biotechnology, Microbial Type Culture Collection and Gene Bank (MTCC), Institute of Microbial Technology (CSIR), Sector-39A, Chandigarh - 160036, India

\begin{abstract}
A Gram-stain-positive, rod-shaped, yellow, non-motile, non-spore-forming, strictly aerobic bacterial strain, designated $\mathrm{MW} 10^{\top}$, was isolated from seawater of the Bay of Bengal, India, and was subjected to a polyphasic taxonomic study. Analysis of the 16S rRNA gene sequence revealed that strain $\mathrm{MW} 10^{\top}$ showed highest similarity to the type strains of Psychrobacillus psychrodurans (96.15\%) and Psychrobacillus psychrotolerans (96.01\%) and showed less than $96 \%$ similarity to members of the genera Paenisporosarcina, Planococcus, Sporosarcina and Planomicrobium. Phylogenetic analysis based on the 16S rRNA gene sequence showed that strain MW $10^{\top}$ formed a clade separate from members of closely related genera. The morphological, physiological and chemotaxonomic characteristics of strain $\mathrm{MW} 10^{\top}$ differed from those of members of closely related genera. The major fatty acid in strain $\mathrm{MW} 10^{\top}$ was iso- $\mathrm{C}_{15: 0}$ and the menaquinones were MK-7 (48.4\%), MK-8 (32.3\%), MK-7 $\left(\mathrm{H}_{2}\right)(13.7 \%)$ and MK-6 (5.6\%). The polar lipids were diphosphatidylglycerol, phosphatidylglycerol, phosphatidylethanolamine, phosphatidylcholine, an unknown phospholipid, an unknown lipid and an unknown glycolipid. The cell-wall peptidoglycan type was L-Lys-D-Asp. The genomic DNA $\mathrm{G}+\mathrm{C}$ content $(53.4 \mathrm{~mol} \%)$ of strain $\mathrm{MW} 10^{\top}$ was significantly different from those of members of closely related genera. On the basis of its morphological, physiological and chemotaxonomic characteristics as well as our phylogenetic analysis, we conclude that strain $\mathrm{MW} 10^{\top}$ is a member of a novel genus and species, for which the name Chryseomicrobium imtechense gen. nov., sp. nov., is proposed. The type strain of Chryseomicrobium imtechense is MW $10^{\top}\left(=\mathrm{MTCC} 10098^{\top}\right.$ $\left.=J C M 16573^{\top}\right)$.
\end{abstract}

In the course of a study of the microbial diversity of the Bay of Bengal, India, a Gram-stain-positive, aerobic, yellow, rod-shaped, non-motile, non-spore-forming bacterium, MW $10^{\mathrm{T}}$, was isolated from a seawater sample collected from Sompet district, Andra Pradesh, at a depth of $30 \mathrm{~m}$, and characterized by polyphasic approach. Strain MW $10^{\mathrm{T}}$ was isolated on tryptone soy agar (TSA) by a dilution plating method and the plate was incubated at $30{ }^{\circ} \mathrm{C}$ for $48 \mathrm{~h}$. Pure cultures were maintained as glycerol stocks at $-70{ }^{\circ} \mathrm{C}$.

Colony morphology was examined following growth of the strain on TSA at $30{ }^{\circ} \mathrm{C}$ for $48 \mathrm{~h}$. Cell morphology was investigated by light microscopy (Zeiss) at $\times 1000$ magnification. Motility was checked using the method

\section{†Deceased.}

The GenBank/EMBL/DDBJ accession number for the 16S rRNA gene sequence of strain MW $10^{\top}$ is GQ927308.

Four supplementary figures are available with the online version of this paper. described by Skerman (1967). The Gram reaction was determined by using the HiMedia Gram staining kit according to the manufacturer's instructions. Spore formation was examined by heat treatment in a water bath at $80{ }^{\circ} \mathrm{C}$ for $10 \mathrm{~min}$ as well as by phase-contrast microscopy at the end of growth of strain MW $10^{\mathrm{T}}$ on different sporulating media. Growth at 4, 10, 15, 20, 25, 30, 35, 40 and $45{ }^{\circ} \mathrm{C}$ was determined on TSA ( $\mathrm{pH} 7.3$ ). Growth at different $\mathrm{pH}$ was tested using tryptone soy broth (TSB) as growth medium adjusted to $\mathrm{pH} 4.5-9.5$ (at intervals of $0.5 \mathrm{pH}$ units) with acetate or citrate buffer ( $\mathrm{pH} 4-6), 100 \mathrm{mM} \mathrm{NaH_{2 }} \mathrm{PO}_{4} /$ $\mathrm{Na}_{2} \mathrm{HPO}_{4}$ (pH 7-8), $100 \mathrm{mM} \mathrm{NaHCO} / \mathrm{Na}_{2} \mathrm{CO}_{3}$ (pH 9-10) or $100 \mathrm{mM} \mathrm{Na} \mathrm{CO}_{3} / \mathrm{NaOH}(\mathrm{pH} 11-12)$. The $\mathrm{pH}$ was adjusted prior to autoclaving. After autoclaving, the $\mathrm{pH}$ was rechecked and recorded as the $\mathrm{pH}$ of growth medium. Growth in the presence of $0.5,1,2,3,4,5,6,7,8$ and 10 $(\mathrm{w} / \mathrm{v}) \mathrm{NaCl}$ was investigated in TSB. Oxidase and catalase activities were determined using oxidase discs (HiMedia) and $3 \%(\mathrm{v} / \mathrm{v}) \mathrm{H}_{2} \mathrm{O}_{2}$, respectively, according to methods described by Smibert \& Krieg (1994). Hydrolysis of casein, gelatin, starch and egg yolk was tested on skimmed-milk 
agar, gelatin agar, starch agar and egg yolk agar, respectively. Biochemical tests such as the methyl red test and VogesProskauer reaction, $\mathrm{H}_{2} \mathrm{~S}$ and indole production, citrate utilization and nitrate reduction were performed according to standard procedures (Cowan \& Steel, 1965). Activity of $\beta$-galactosidase was determined using $o$-nitrophenyl $\beta$-D-galactopyranoside (ONPG) discs (HiMedia). Acid production from various carbohydrates was tested as described by Claus \& Berkeley (1986).

Oxidation of various substrates as sole carbon, nitrogen and energy sources was tested using the Biolog GP2 MicroPlate in accordance with the manufacturer's instructions, except that TSB was used instead of Biolog universal growth agar. The microplate, inoculated with strain MW $10^{\mathrm{T}}$, was incubated for $48 \mathrm{~h}$ and the results were read with a MicroPlate Reader using Microlog 4.2 computer software for automated reading.

For analysis of menaquinones, polar lipids and peptidoglycan, freeze-dried cells were prepared following growth of strain MW $10^{\mathrm{T}}$ in TSB for $48 \mathrm{~h}$ at $30{ }^{\circ} \mathrm{C}$. Polar lipids were extracted following the method of Bligh \& Dyer (1959) and analysed by two-dimensional TLC followed by spraying with appropriate detection reagents (Komagata \& Suzuki, 1987). Menaquinones were extracted by the method of Minnikin et al. (1984) and identified by HPLC. The peptidoglycan structure was determined by using a hydrolysate of purified cell walls, according to Schleifer \& Kandler (1972). For analysis of cellular fatty acids, strain MW $10^{\mathrm{T}}$ and a number of reference strains were grown on TSA plates at $30{ }^{\circ} \mathrm{C}$ for $48 \mathrm{~h}$; fatty acid methyl esters were extracted and analysed as described by Pandey et al. (2002) using the Microbial Identification System (MIDI). The $\mathrm{G}+\mathrm{C}$ content of genomic DNA was determined spectrophotometrically (Lambda 35; Perkin Elmer) using the thermal denaturation method (Mandel \& Marmur, 1968).

The 16S rRNA gene was amplified by PCR using the universal primers 8 -27F (5'-AGAGTTTGATCCTGGCTCAG-3') and 1492R (5'-TACGGYTACCTTGTTACGACTT- $\left.3^{\prime}\right)$. Amplification and purification of the product was done as described by Pandey et al. (2002). The amplified $16 \mathrm{~S}$ rRNA gene was sequenced by the dideoxy chain terminator method using a Big Dye terminator kit followed by capillary electrophoresis on an ABI 310 Genetic Analyzer (Applied Biosystems). The primers used for sequencing were 27F, 357F (5'-CTCCTACGGGAGGCAGCAG-3'), 518R (5'-ATTACCGCGGCTGCTGG-3'), 704F (5'-GTAGCGGTGAAATGCGTAGA-3'), 1100R ( $5^{\prime}$-GGGTTGCGCTCGTTG-3') and 1492R. The 16S rRNA gene sequences of closely related strains were retrieved from the GenBank database using BLASTN (Altschul et al., 1997). Sequences were aligned with CLUSTAL W 1.8 (Thompson et al., 1994). Phylogenetic trees were constructed by the neighbour-joining (Saitou \& Nei, 1987), minimumevolution (Rzhetsky \& Nei, 1992) and maximum-parsimony (Fitch, 1971) methods with the MEGA 4 program package
(Tamura et al., 2007). Evolutionary distances were calculated according to the algorithm of Kimura's two-parameter model (Kimura, 1980) for the neighbour-joining method.

Strain MW $10^{\mathrm{T}}$ formed yellow colonies and cells were Gram-stain-positive, aerobic, non-motile rods. Spores were never observed under any of the tested growth conditions. Spore staining of cells grown on sporulating agar showed no spore formation in strain MW $10^{\mathrm{T}}$ (Supplementary Fig. S1, available in IJSEM Online). Furthermore, strain MW $10^{\mathrm{T}}$ could not survive heat treatment at $80{ }^{\circ} \mathrm{C}$ for $10 \mathrm{~min}$, confirming the absence of spore formation. Morphological, physiological, biochemical and chemotaxonomic characteristics of strain $\mathrm{MW} 10^{\mathrm{T}}$ are given in genus and species descriptions.

The 16S rRNA gene sequence (1430 nt) of strain MW $10^{\mathrm{T}}$ was compared with sequences of closely related type strains retrieved from the GenBank database. Strain MW $10^{\mathrm{T}}$ showed highest $16 \mathrm{~S}$ rRNA gene sequence similarity to type strains of the genus Psychrobacillus (96.15\% similarity with Psychrobacillus psychrodurans DSM $11713^{\mathrm{T}}, 96.01 \%$ with Psychrobacillus psychrotolerans DSM $11706^{\mathrm{T}}$ and $95.24 \%$ with Psychrobacillus insolitus DSM $5^{\mathrm{T}}$ ). Strain MW $10^{\mathrm{T}}$ showed less than $96 \%$ similarity to members of the genera Paenisporosarcina, Planomicrobium, Planococcus and Sporosarcina. Strain MW $10^{\mathrm{T}}$ also differed from closely related genera in its phenotypic and genotypic characteristics (Table 1). Strain MW $10^{\mathrm{T}}$ differed from all members of the genera Psychrobacillus, Paenisporosarcina and Sporosarcina in the absence of endospores and also differed from members of the genera Planomicrobium and Planococcus in several other phenotypic characteristics, as shown in Table 1.

Comparison of the cellular fatty acid profiles of strain MW $10^{\mathrm{T}}$ and species of the related genera Psychrobacillus, Paenisporosarcina, Sporosarcina, Planococcus and Planomicrobium showed significant differences. The major fatty acid of strain MW $10^{\mathrm{T}}$ was iso- $\mathrm{C}_{15: 0}$, which made up $68.57 \%$ of the total fatty acids. Significant amounts of this fatty acid $(>10 \%)$ were present in type strains of the related genera Psychrobacillus and Paenisporosarcina; however, type strains of the genera Sporosarcina, Planococcus and Planomicrobium contained smaller amounts $(<10 \%$ or even trace amounts) of iso- $\mathrm{C}_{15: 0}$ (Table 2). anteiso- $\mathrm{C}_{15: 0}$ was present either in significant amounts $(>22 \%)$ or as a major fatty acid (26$62 \%)$ in type strains of the genera Psychrobacillus, Paenisporosarcina, Sporosarcina, Planomicrobium and Planococcus, whereas only a small amount of anteiso- $\mathrm{C}_{15: 0}$ $(2.52 \%)$ was observed in strain MW $10^{\mathrm{T}}$.

Analysis of polar lipids using two-dimensional TLC revealed that the polar lipid profile of strain MW $10^{\mathrm{T}}$ included diphosphatidylglycerol, phosphatidylglycerol, phosphatidylethanolamine, phosphatidylcholine, an unknown phospholipid, an unknown lipid and an unknown glycolipid (Supplementary Fig. S2). Diphosphatidylglycerol, phosphatidylglycerol and phosphatidylethanolamine were also reported as major polar lipids in members of the genera 
Table 1. Characteristics that distinguish strain $\mathrm{MW} 10^{\top}$ from closely related genera

Data for reference genera were taken from Krishnamurthi et al. (2010) (Psychrobacillus), Krishnamurthi et al. (2009) (Paenisporosarcina and Sporosarcina), Kwon et al. (2007) (Sporosarcina), Yoon et al. (2010) and Nakagawa et al. (1996) (Planococcus) and Yoon et al. (2001) and Zhang et al. (2009) (Planomicrobium).

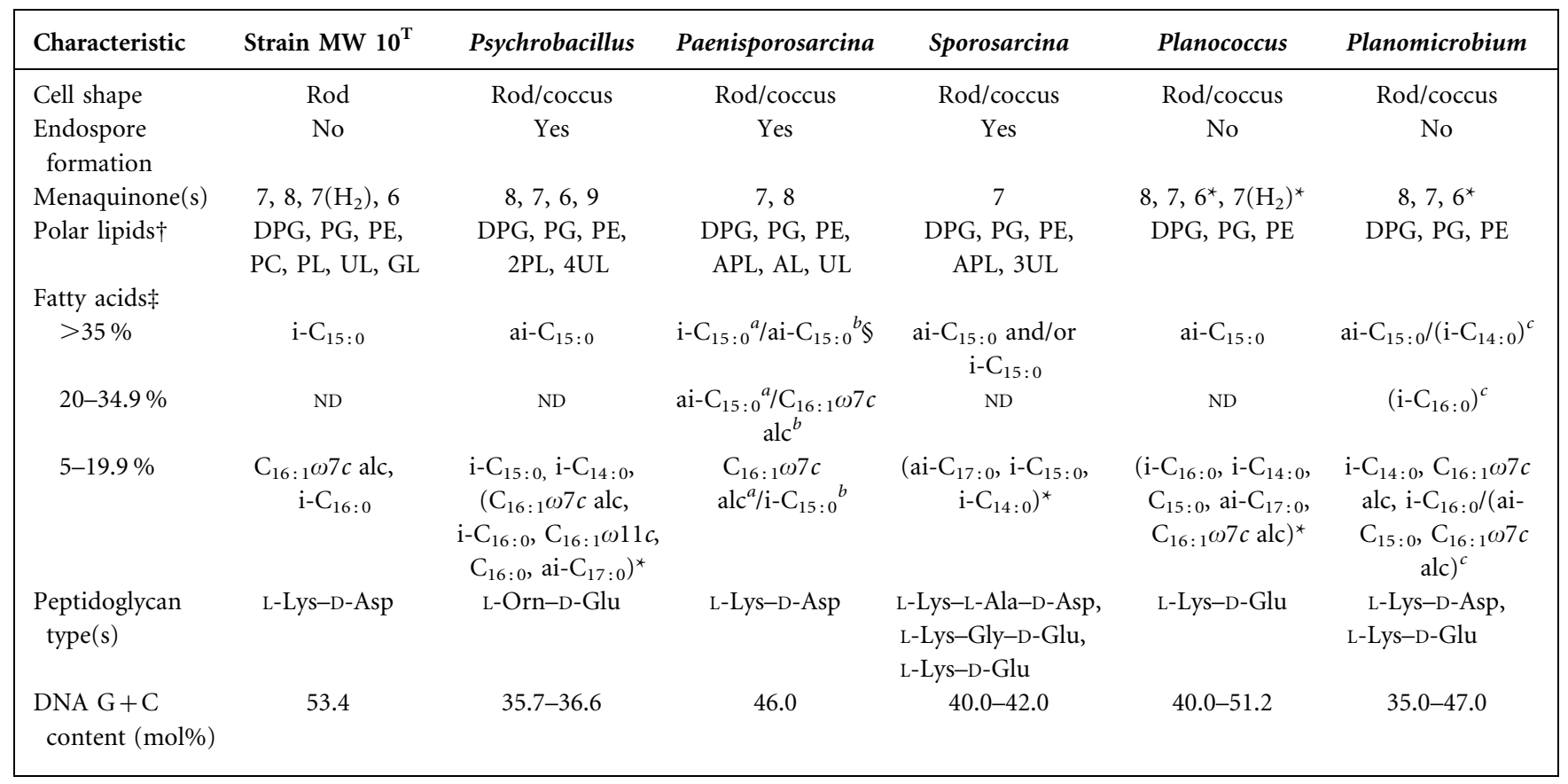

${ }^{*}$ Component present in some members of the taxon.

$\nmid$ DPG, Diphosphatidylglycerol; PG, phosphatidylglycerol; PE, phosphatidylethanolamine; PC, phosphatidylcholine; PL, unknown phospholipid; UL, unknown lipid; GL, unknown glycolipid; APL, unknown aminophospholipid; AL, unknown aminolipid.

‡Classified by proportion of total fatty acids; ND, none detected. ai, Anteiso-branched; alc, alcohol; i, iso-branched.

$\S$ Fatty acids present in: a, Paenisporosarcina quisquiliarum MTCC $7604^{\mathrm{T}}$; b, Paenisporosarcina macmurdoensis MTCC $4670^{\mathrm{T}}$; $c$, Planomicrobium okeanokoites NBRC $12536^{\mathrm{T}}$.

Psychrobacillus, Paenisporosarcina, Sporosarcina, Planococcus and Planomicrobium (Krishnamurthi et al., 2009, 2010; Mayilraj et al., 2005; Romano et al., 2003; Suresh et al., 2007; Yoon et al., 2001, 2010; Yu et al., 2008). However, phosphatidylcholine, detected in strain MW $10^{\mathrm{T}}$, was not found in closely related genera.

The menaquinone profile of strain MW $10^{\mathrm{T}}$ consisted of MK-7 (48.4\%), MK-8 (32.3\%), MK-7 $\left(\mathrm{H}_{2}\right)(13.7 \%)$ and MK-6 (5.6\%). MK-7 and MK-8 were reported as predominant menaquinones in members of the genera Psychrobacillus, Planococcus, Planomicrobium and Paenisporosarcina (Alam et al., 2003; Choi et al., 2007; Dai et al., 2005; Jung et al., 2009; Krishnamurthi et al., 2009; Zhang et al., 2009) whereas, in members of the genus Sporosarcina, MK-7 was reported as the major menaquinone (Reddy et al., 2003; Yu et al., 2008). MK-6 was also present in minor amounts in some members of the genera Planomicrobium and Planococcus (Yoon et al., 2001, 2010). MK-7 $\left(\mathrm{H}_{2}\right)$ was reported in Planococcus columbae (Suresh et al., 2007); however, MK-7 $\left(\mathrm{H}_{2}\right)$ was not present in the genera Psychrobacillus, Paenisporosarcina, Sporosarcina or Planomicrobium.
Strain MW $10^{\mathrm{T}}$ had cell-wall peptidoglycan type $\mathrm{A} 4 \alpha$ (L-Lys-D-Asp), which was also reported in species of the genus Paenisporosarcina (Krishnamurthi et al., 2009) and a few species of the genus Planomicrobium (Yoon et al., 2001). However, the peptidoglycan type of strain MW $10^{\mathrm{T}}$ differed from those of members of the genera Psychrobacillus, Sporosarcina and Planococcus.

The DNA G + C content of strain MW $10^{\mathrm{T}}$ was $53.4 \mathrm{~mol} \%$. This value is significantly higher than those reported for members of the genera Paenisporosarcina, Sporosarcina, Planomicrobium and Planococcus (Table 1).

Phylogenetic analysis based on the 16S rRNA gene sequence showed that strain MW $10^{\mathrm{T}}$ fell within the family Planococcaceae and formed a clade separate from species of the genera Planomicrobium and Planococcus (Fig. 1). Strain MW $10^{\mathrm{T}}$ was separated phylogenetically from all closely related genera of the family Planococcaceae (Fig. 1 and Supplementary Figs S3 and S4).

On the basis of the phenotypic characteristics and phylogenetic analysis, strain MW $10^{\mathrm{T}}$ cannot be assigned to any recognized bacterial genus in the family 
Table 2. Comparison of the fatty acid profiles of strain $M W 10^{\top}$ and type strains of related species

Strains: 1, strain MW $10^{\mathrm{T}} ; 2$, Psychrobacillus psychrotolerans DSM $11706^{\mathrm{T}} ; 3$, Psychrobacillus psychrodurans DSM 11713 $;$, Psychrobacillus insolitus DSM $5^{\mathrm{T}} ; 5$, Paenisporosarcina quisquiliarum MTCC $7604^{\mathrm{T}} ; 6$, Paenisporosarcina macmurdoensis MTCC $4670^{\mathrm{T}} ; 7$, Sporosarcina ureae DSM $2281^{\mathrm{T}}$ (data in columns 1-7 from the present study); 8, Planococcus citreus DSM 20549 ${ }^{\mathrm{T}}$ (data from Yoon et al., 2001); 9, Planomicrobium koreense JCM $10704^{\mathrm{T}}$ (Zhang et al., 2009). Major differences are highlighted in bold. ND, Not detected/not reported; tr, trace.

\begin{tabular}{|c|c|c|c|c|c|c|c|c|c|}
\hline Fatty acid & 1 & 2 & 3 & 4 & 5 & 6 & 7 & 8 & 9 \\
\hline \multicolumn{10}{|l|}{ Saturated fatty acids } \\
\hline $\mathrm{C}_{14: 0}$ & ND & 0.78 & 0.84 & ND & 0.90 & 0.61 & 0.99 & ND & ND \\
\hline $\mathrm{C}_{15: 0}$ & ND & $\mathrm{ND}$ & ND & ND & $\mathrm{ND}$ & $\mathrm{ND}$ & $\mathrm{ND}$ & 6.7 & ND \\
\hline $\mathrm{C}_{16: 0}$ & 1.51 & 0.81 & 3.48 & 11.91 & 1.98 & ND & 2.57 & ND & 2.8 \\
\hline $\mathrm{C}_{17: 0}$ & $\mathrm{ND}$ & ND & ND & $\mathrm{ND}$ & ND & ND & ND & 2.3 & ND \\
\hline $\mathrm{C}_{18: 0}$ & ND & ND & 1.93 & ND & 1.19 & 2.57 & ND & ND & ND \\
\hline \multicolumn{10}{|c|}{ Unsaturated fatty acids } \\
\hline $\mathrm{C}_{16: 1} \omega 7 c$ alcohol & 10.88 & 8.67 & 4.54 & 8.92 & 9.47 & 20.29 & 3.26 & 9.8 & 9.6 \\
\hline $\mathrm{C}_{16: 1} \omega 11 c$ & 1.86 & 0.75 & 0.93 & 11.61 & 1.87 & 1.48 & 4.37 & 2.5 & 4.0 \\
\hline \multicolumn{10}{|l|}{ Branched fatty acids } \\
\hline iso- $\mathrm{C}_{14: 0}$ & 2.81 & 12.45 & 5.05 & 12.97 & 4.52 & 0.61 & 3.58 & 8.8 & 16.2 \\
\hline iso- $\mathrm{C}_{15: 0}$ & 68.57 & 13.62 & 10.52 & 9.17 & 41.45 & 10.38 & 7.32 & $\mathrm{ND}$ & 6.3 \\
\hline anteiso- $\mathrm{C}_{15: 0}$ & 2.52 & 51.60 & 48.09 & 35.60 & 22.65 & 38.85 & 61.81 & 52.1 & 43.6 \\
\hline iso- $\mathrm{C}_{16: 0}$ & 6.42 & 4.23 & 8.38 & 9.80 & 3.28 & 2.66 & 1.36 & 8.1 & 6.8 \\
\hline iso- $\mathrm{C}_{17: 0}$ & 3.00 & $\mathrm{ND}$ & ND & $\mathrm{ND}$ & 1.29 & $\mathrm{ND}$ & $\mathrm{ND}$ & ND & $\operatorname{tr}$ \\
\hline anteiso- $\mathrm{C}_{17: 0}$ & $\mathrm{ND}$ & 3.01 & 13.48 & ND & 2.56 & 1.09 & 8.67 & 5.2 & 2.9 \\
\hline iso- $\mathrm{C}_{17: 1} \omega 10 c$ & 2.43 & $\mathrm{ND}$ & $\mathrm{ND}$ & ND & 2.52 & $\mathrm{ND}$ & 0.86 & ND & ND \\
\hline iso- $\mathrm{C}_{18: 0}$ & $\mathrm{ND}$ & 0.40 & ND & ND & $\mathrm{ND}$ & $\mathrm{ND}$ & $\mathrm{ND}$ & ND & ND \\
\hline Summed feature $4^{*}$ & ND & 2.85 & 2.81 & ND & 5.92 & 7.98 & 4.40 & 4.5 & ND \\
\hline
\end{tabular}

${ }^{*}$ Summed feature 4 represents iso- $\mathrm{C}_{17: 1} \mathrm{I}$ and/or anteiso- $\mathrm{C}_{17: 1} \mathrm{~B}$, which could not be separated by GLC with the MIDI system.

Planococcaceae. Therefore, we propose a new genus and species, Chryseomicrobium imtechense gen. nov., sp. nov., to accommodate strain MW $10^{\mathrm{T}}$.

\section{Description of Chryseomicrobium gen. nov.}

Chryseomicrobium (Chry'se.o.mi.cro'bi.um. Gr. adj. chruseos golden; N.L. neut. n. microbium microbe from Gr. adj. mikros small and Gr. n. bios life; N.L. neut. n. Chryseomicrobium yellow microbe).

Cells are Gram-stain-positive, aerobic, non-motile, nonspore-forming rods. Catalase-positive and oxidase-negative. The major fatty acid is iso- $\mathrm{C}_{15: 0}$. The menaquinones are MK-7, MK-8, MK-7 $\left(\mathrm{H}_{2}\right)$ and MK-6. The cell-wall peptidoglycan is of the A4 $\alpha$ type with an interpeptide bridge L-Lys-D-Asp. The polar lipids are diphosphatidylglycerol, phosphatidylglycerol, phosphatidylethanolamine, phosphatidylcholine, an unknown phospholipid, an unknown lipid and an unknown glycolipid. The genomic DNA G+C content of the type strain of the type species is $53.4 \mathrm{~mol} \%$. The type species is Chryseomicrobium imtechense.

\section{Description of Chryseomicrobium imtechense sp. nov.}

Chryseomicrobium imtechense [im.tech.en'se. N.L. neut. adj. imtechense pertaining to the Institute of Microbial
Technology (IMTECH), where the type strain was characterized].

Displays the following properties in addition to those described for the genus. Forms yellow colonies. Cells are $0.3-0.7 \mu \mathrm{m}$ wide and $1.7-2.9 \mu \mathrm{m}$ long. Grows at $4-45^{\circ} \mathrm{C}$, pH 6-9 and 0-6\% NaCl. Casein is hydrolysed but gelatin, starch and aesculin are not. Egg yolk reaction and oxidase test are negative. $\mathrm{H}_{2} \mathrm{~S}$ production, indole formation and urease test are negative. Methyl red test, Voges-Proskauer test and oxidation/fermentation test are negative. Does not hydrolyse ONPG. No growth on MacConkey or Simmons' citrate agar. Nitrate is not reduced to nitrite. Acid is produced from glucose, salicin, fructose, maltose, sucrose, inulin, melibiose and cellobiose. In the Biolog GP2 system, positive for oxidation of $\alpha$-ketovaleric acid, glycerol, $\gamma$-hydroxybutyric acid, pyruvic acid, L-serine, D-ribose, pyruvic acid methyl ester, L-alanine, 2-deoxyadenosine and L-arabinose and negative for oxidation of $\alpha$ - and $\beta$-cyclodextrin, glycogen, inulin, mannan, lactose, methyl $\beta$-D-glucoside, L-alaninamide, trehalose, D-lactic acid methyl ester, D-alanine, arbutin, L-lactic acid, xylitol, D- and L-malic acid, raffinose, L-asparagine, L-fucose, L-rhamnose, adenosine $5^{\prime}$-monophosphate, melezitose, $\alpha$-hydroxybutyric acid, glycyl L-glutamic acid, Tweens 40 and 80, D-galacturonic acid, melibiose, salicin, propionic acid, L-pyroglutamic acid, uridine $5^{\prime}$-monophosphate, gentiobiose, methyl $\alpha$-D-galactoside, sedoheptulosan, D-fructose 6-phosphate, $N$-acetyl- $\beta$-glucosamine, 


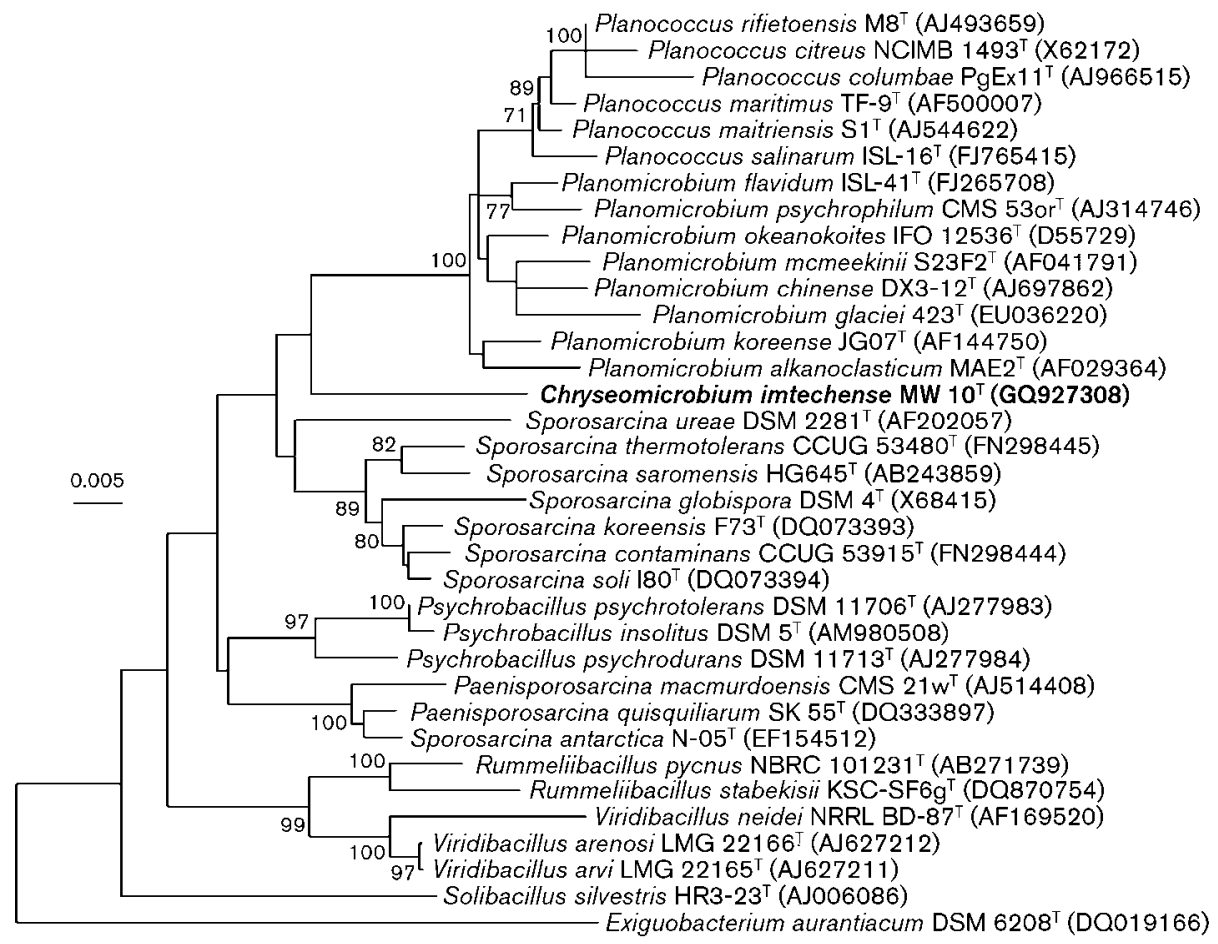

Fig. 1. Neighbour-joining phylogenetic tree based on $16 \mathrm{~S}$ rRNA gene sequences showing the positions of strain $\mathrm{MW} 10^{\top}$ and related taxa. Bootstrap values (expressed as percentages of 1000 replications) $>70 \%$ are shown at branch points. Bar, 0.005 substitutions per nucleotide position.

D-gluconic acid, methyl $\beta$-D-galactoside, D-sorbitol, $p$-hydroxyphenylacetic acid, succinamic acid, putrescine, $\alpha$-D-glucose 1 -phosphate, amygdalin, myo-inositol, methyl $\alpha$-D-glucoside, sucrose, $N$-acetyl L-glutamic acid and DL- $\alpha$-glycerol phosphate. The cellular fatty acid profile includes $\mathrm{C}_{16: 0}, \mathrm{C}_{16: 1} \omega 7 c$ alcohol, $\mathrm{C}_{16: 1} \omega 11 c$, iso- $\mathrm{C}_{14: 0}$, iso- $\mathrm{C}_{15: 0}$, anteiso- $\mathrm{C}_{15: 0}$, iso- $\mathrm{C}_{16: 0}$, iso$\mathrm{C}_{17: 0}$ and iso- $\mathrm{C}_{17: 1} \omega 10 c$.

The type strain, MW $10^{\mathrm{T}}\left(=\mathrm{MTCC} 10098^{\mathrm{T}}=\mathrm{JCM}\right.$ $\left.16573^{\mathrm{T}}\right)$, was isolated from a seawater sample collected from the Bay of Bengal, India.

\section{Acknowledgements}

The authors are grateful to the Council of Scientific and Industrial Research (CSIR), Government of India, for financial support.

\section{References}

Alam, S. I., Singh, L., Dube, S., Reddy, G. S. N. \& Shivaji, S. (2003). Psychrophilic Planococcus maitriensis sp. nov. from Antarctica. Syst Appl Microbiol 26, 505-510.

Altschul, S. F., Madden, T. L., Schäffer, A. A., Zhang, J., Zhang, Z., Miller, W. \& Lipman, D. J. (1997). Gapped BLAST and PSI-BLAST: a new generation of protein database search programs. Nucleic Acids Res 25, 3389-3402.

Bligh, E. G. \& Dyer, W. J. (1959). A rapid method of total lipid extraction and purification. Can J Biochem Physiol 37, 911-917.
Choi, J.-H., Im, W.-T., Liu, Q.-M., Yoo, J.-S., Shin, J.-H., Rhee, S.-K. \& Roh, D.-H. (2007). Planococcus donghaensis sp. nov., a starchdegrading bacterium isolated from the East Sea, South Korea. Int J Syst Evol Microbiol 57, 2645-2650.

Claus, D. \& Berkeley, R. C. W. (1986). Genus Bacillus Cohn 1872, $174^{\mathrm{AL}}$. In Bergey's Manual of Systematic Bacteriology, vol. 2, pp. 1051139. Edited by P. H. A. Sneath, N. S. Mair, M. E. Sharpe \& J. G. Holt. Baltimore: Williams \& Wilkins.

Cowan, S. T. \& Steel, K. J. (1965). Manual for the Identification of Medical Bacteria. London: Cambridge University Press.

Dai, X., Wang, Y.-N., Wang, B.-J., Liu, S.-J. \& Zhou, Y.-G. (2005). Planomicrobium chinense sp. nov., isolated from coastal sediment, and transfer of Planococcus psychrophilus and Planococcus alkanoclasticus to Planomicrobium as Planomicrobium psychrophilum comb. nov. and Planomicrobium alkanoclasticum comb. nov. Int J Syst Evol Microbiol 55, 699-702.

Fitch, W. M. (1971). Toward defining the course of evolution: minimum change for a specific tree topology. Syst Zool 20, 406416.

Jung, Y.-T., Kang, S.-J., Oh, T.-K., Yoon, J.-H. \& Kim, B.-H. (2009). Planomicrobium flavidum sp. nov., isolated from a marine solar saltern, and transfer of Planococcus stackebrandtii Mayilraj et al. 2005 to the genus Planomicrobium as Planomicrobium stackebrandtii comb. nov. Int J Syst Evol Microbiol 59, 2929-2933.

Kimura, M. (1980). A simple method for estimating evolutionary rates of base substitutions through comparative studies of nucleotide sequences. J Mol Evol 16, 111-120.

Komagata, K. \& Suzuki, K. (1987). Lipid and cell-wall analysis in bacterial systematics. Methods Microbiol 19, 161-207. 
Krishnamurthi, S., Bhattacharya, A., Mayilraj, S., Saha, P., Schumann, P. \& Chakrabarti, T. (2009). Description of Paenisporosarcina quisquiliarum gen. nov., sp. nov., and reclassification of Sporosarcina macmurdoensis Reddy et al. 2003 as Paenisporosarcina macmurdoensis comb. nov. Int J Syst Evol Microbiol 59, 1364-1370.

Krishnamurthi, S., Ruckmani, A., Pukall, R. \& Chakrabarti, T. (2010). Psychrobacillus gen. nov. and proposal for reclassification of Bacillus insolitus Larkin \& Stokes, 1967, B. psychrotolerans Abd-El Rahman et al., 2002 and B. psychrodurans Abd-El Rahman et al., 2002 as Psychrobacillus insolitus comb. nov., Psychrobacillus psychrotolerans comb. nov. and Psychrobacillus psychrodurans comb. nov. Syst Appl Microbiol 33, 367-373.

Kwon, S.-W., Kim, B.-Y., Song, J., Weon, H.-Y., Schumann, P., Tindall, B. J., Stackebrandt, E. \& Fritze, D. (2007). Sporosarcina koreensis sp. nov. and Sporosarcina soli sp. nov., isolated from soil in Korea. Int J Syst Evol Microbiol 57, 1694-1698.

Mandel, M. \& Marmur, J. (1968). Use of ultraviolet absorbancetemperature profile for determining the guanine plus cytosine content of DNA. Methods Enzymol 12B, 195-206.

Mayilraj, S., Prasad, G. S., Suresh, K., Saini, H. S., Shivaji, S. \& Chakrabarti, T. (2005). Planococcus stackebrandtii sp. nov., isolated from a cold desert of the Himalayas, India. Int J Syst Evol Microbiol 55, 91-94.

Minnikin, D. E., O'Donnell, A. G., Goodfellow, M., Alderson, G., Athalye, M., Schaal, A. \& Parlett, J. H. (1984). An integrated procedure for the extraction of bacterial isoprenoid quinones and polar lipids. J Microbiol Methods 2, 233-241.

Nakagawa, Y., Sakane, T. \& Yokota, A. (1996). Emendation of the genus Planococcus and transfer of Flavobacterium okeanokoites Zobell and Upham 1944 to the genus Planococcus as Planococcus okeanokoites comb. nov. Int J Syst Bacteriol 46, 866-870.

Pandey, K. K., Mayilraj, S. \& Chakrabarti, T. (2002). Pseudomonas indica sp. nov., a novel butane-utilizing species. Int J Syst Evol Microbiol 52, 1559-1567.

Reddy, G. S. N., Matsumoto, G. I. \& Shivaji, S. (2003). Sporosarcina macmurdoensis sp. nov., from a cyanobacterial mat sample from a pond in the McMurdo Dry Valleys, Antarctica. Int J Syst Evol Microbiol 53, 1363-1367.

Romano, I., Giordano, A., Lama, L., Nicolaus, B. \& Gambacorta, A. (2003). Planococcus rifietensis sp. nov., isolated from algal mat collected from a sulfurous spring in Campania (Italy). Syst Appl Microbiol 26, 357-366.
Rzhetsky, A. \& Nei, M. (1992). A simple method for estimating and testing minimum evolution trees. Mol Biol Evol 9, 945-967.

Saitou, N. \& Nei, M. (1987). The neighbor-joining method: a new method for reconstructing phylogenetic trees. Mol Biol Evol 4, 406425.

Schleifer, K. H. \& Kandler, O. (1972). Peptidoglycan types of bacterial cell walls and their taxonomic implications. Bacteriol Rev 36, 407-477.

Skerman, V. B. D. (1967). A Guide to the Identification of the Genera of Bacteria, 2nd edn. Baltimore: Williams \& Wilkins.

Smibert, R. M. \& Krieg, N. R. (1994). Phenotypic characterization. In Methods for General and Molecular Bacteriology, pp. 607-654. Edited by P. Gerhardt, R. G. E. Murray, W. A. Wood \& N. R. Krieg. Washington, DC: American Society for Microbiology.

Suresh, K., Mayilraj, S., Bhattacharya, A. \& Chakrabarti, T. (2007). Planococcus columbae sp. nov., isolated from pigeon faeces. Int J Syst Evol Microbiol 57, 1266-1271.

Tamura, K., Dudley, J., Nei, M. \& Kumar, S. (2007). MEGA4: molecular evolutionary genetics analysis (MEGA) software version 4.0. Mol Biol Evol 24, 1596-1599.

Thompson, J. D., Higgins, D. G. \& Gibson, T. J. (1994). CLUSTAL W: improving the sensitivity of progressive multiple sequence alignment through sequence weighting, position-specific gap penalties and weight matrix choice. Nucleic Acids Res 22, 4673-4680.

Yoon, J.-H., Kang, S.-S., Lee, K.-C., Lee, E. S., Kho, Y. H., Kang, K. H. \& Park, Y. H. (2001). Planomicrobium koreense gen. nov., sp. nov., a bacterium isolated from the Korean traditional fermented seafood jeotgal, and transfer of Planococcus okeanokoites (Nakagawa et al. 1996) and Planococcus momeekinii (Junge et al. 1998) to the genus Planomicrobium. Int J Syst Evol Microbiol 51, 1511-1520.

Yoon, J.-H., Kang, S.-J., Lee, S.-Y., Oh, K.-H. \& Oh, T.-K. (2010). Planococcus salinarum sp. nov., isolated from a marine solar saltern, and emended description of the genus Planococcus. Int J Syst Evol Microbiol 60, 754-758.

Yu, Y., Xin, Y.-H., Liu, H.-C., Chen, B., Sheng, J., Chi, Z.-M., Zhou, P.-J. \& Zhang, D.-C. (2008). Sporosarcina antarctica sp. nov., a psychrophilic bacterium isolated from the Antarctic. Int J Syst Evol Microbiol 58, 2114-2117.

Zhang, D.-C., Liu, H.-C., Xin, Y.-H., Yu, Y., Zhou, P.-J. \& Zhou, Y. G. (2009). Planomicrobium glaciei sp. nov., a psychrotolerant bacterium isolated from a glacier. Int J Syst Evol Microbiol 59, 1387-1390. 